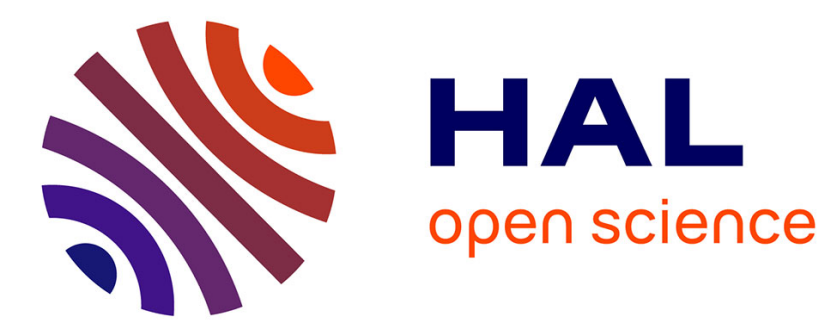

\title{
Promise engineering: Investment and its conflicting anticipations in the French mining revival
}

\author{
Julien Merlin, Brice Laurent, Yann Gunzburger
}

\section{To cite this version:}

Julien Merlin, Brice Laurent, Yann Gunzburger. Promise engineering: Investment and its conflicting anticipations in the French mining revival. Economy and Society, 2021, pp.1-28. 10.1080/03085147.2021.1903772 . hal-03265197

HAL Id: hal-03265197

https://hal-mines-paristech.archives-ouvertes.fr/hal-03265197

Submitted on 19 Jun 2021

HAL is a multi-disciplinary open access archive for the deposit and dissemination of scientific research documents, whether they are published or not. The documents may come from teaching and research institutions in France or abroad, or from public or private research centers.
L'archive ouverte pluridisciplinaire HAL, est destinée au dépôt et à la diffusion de documents scientifiques de niveau recherche, publiés ou non, émanant des établissements d'enseignement et de recherche français ou étrangers, des laboratoires publics ou privés. 


\title{
Promise engineering: Investment and its conflicting anticipations in the French mining revival
}

\author{
Julien Merlin, Brice Laurent and Yann Gunzburger
}

Julien Merlin (corresponding author) Grenoble-Alpes University, CNRS, Sciences Po Grenoble, PACTE, 14bis, avenue Marie Reynoard, 38100 Grenoble, France. E-mail: julien.merlin@outlook.com

Brice Laurent, MINES ParisTech, PSL Research University, CSI-Centre de Sociologie de l'Innovation, i3 UMR CNRS, 60 Bd St Michel 75006 Paris, France. E-mail:

brice.laurent@mines-paristech.fr

Yann Gunzburger, Université de Lorraine - CNRS, UMR 7359, GeoRessources, Mines

Nancy, Campus Artem, BP 14234, 54042 Nancy cedex, France. E-mail:

yann.gunzburger@univ-lorraine.fr

\begin{abstract}
This paper analyses promises made by companies to various publics, including global investors, national public administrative bodies, and local populations. We speak of 'promise engineering' to describe both the integration of the making of promises in mining exploration operations, and the attempted articulation of promises made to different publics with different concerns. We focus on the French 'mining revival', which prompted exploration projects that became controversial, and integrated a government-led approach meant to introduce an objective of 'responsibility' in mining operations. Mining junior companies attempted to make promises that were both technical and social, while responsibility proved consistent with the crucial role of financial investment. We show that promise engineering offers an analytical lens for studying anticipation practices in industrial projects and the opposition these projects face.
\end{abstract}

Keywords: mining exploration; financial investment; speculation; anticipation; responsibility; promise engineering; controversies.

\section{Introduction}

On 17 April 2018, two collectives opposed to mineral exploration projects in Brittany (France) issued a press release expressing their concerns about the sale of Variscan Mines, a French subsidiary of the Australian company Variscan Ltd, to another exploration company, Apollo Minerals:

Is turning mining licenses into simple stock assets subject to international speculation consistent with the government's objective of reviving mining in France in order to provide French industry with an autonomous supply of raw materials? Can we remain passive in the face of this evolution, which raises serious uncertainties about the medium- and long-term development of our regions? ${ }^{1}$ 
This statement is indicative of the emergence of an opposition to new mining projects in mainland France. Opponents' concerns focus on a variety of issues, ranging from the technical, environmental and social aspects of both preliminary exploration and mining itself, to economic and political considerations. Central to their critical positions is the financial nature of the French mining revival program, its problematic link to national sovereignty, and the 'international speculation' on which they claim it is based.

This paper focuses on the French mining revival program in order to investigate the connections between the methods mining companies use to attract investors and the oppositions to exploration projects. We argue that these oppositions can be better understood by analysing how companies anticipate the risks and benefits of their projects, in ways that are always addressed to certain audiences. More precisely, we analyse the ways in which companies attempt to convince different publics (investors, local communities and public bodies) of the benefits of future mining projects. As our introductory example shows, companies' efforts at persuasion are not always simultaneously successful for all their publics. As such, France's mining revival and the controversies it has generated provide an interesting case for analysing the ways in which the actors involved in conducting technical projects construct expectations about the future developments of these projects. We characterise this process as 'promise engineering' to point to the dual fact that companies integrate the elaboration of promises in their technical projects, and attempt to articulate promises addressed to different (and sometimes conflicting) publics.

The cases we examine are all related to the exploration phase of mining projects. Mining operations are traditionally divided between 'exploration', during which preliminary interventions are meant to evaluate the geological potential of the site, and 'exploitation', during which mineral resources are extracted and processed. The first phase is risky, yet highly profitable if it leads to discovering a mineral deposit. This makes it a promising ground for speculation. There are cases where speculation is deliberately misleading. A well-known example of fraud occurred at Indonesia's Busang gold mine, where investors made huge profits on the basis of falsified core-sample analyses, and about which anthropologist Anna Tsing (2011) coined the term 'economy of appearances'. This case of deliberate fraud is particular, but in all cases, exploration relies on a heterogeneous set of information, which always raises issues for those in charge of assessing it, be they investors, policy makers (Majury, 2014, or affected populations (Geenen, 2018). Exploration builds on 'composites of economic probabilities, technological feasibilities, and geological potentials' (Weszkalnys, 2015), themselves associated with diverse methods, including calculations, qualitative reference to past explorations, and survey drilling in later phases. While doing so, explorers, often in competition with each others (Dougherty, 2011), need to attract interests from potential investors, policy makers and wary publics, without knowing how they will stand. To do so, they use diverse discursive and regulatory devices, some of which will be described in this paper. This means that the 'engineering' of promises related to mining exploration is necessarily messy. It associates calculated previsions and mere imaginary prospects, promising discourses and technical evaluations. It operates in situations of pervasive uncertainty while also manipulating it (Geenen, 2018). It is a kind of 'heterogeneous engineering' (Law, 1987), which is heterogeneous not just in that it associates technical and social elements, but also because it draws on diverse resources of uneven stability.

As they attempt to model, predict or imagine future developments, the actors of mining exploration rely on anticipations that tie technical evaluation and financial speculation, and incite others to engage in other anticipatory practices, possibly at odds with those of the industry (Weszkalnys, 2014). Such dynamics can be identified in all the places where exploration projects are conducted, including developed countries such as Australia and 
Canada where extraction represents a significant share of the national economy, and perhaps even more in countries in the Global South where the objectives of international interventions over the past years have been to attract foreign investors and privatize mining operations. Within this global landscape, the case of France is particular, and, we argue, offers a privileged site for studying the making and reception of promises. It is situated in a European context characterized by an emphasis put on mining activities throughout the EU in the 2000s and $2010 \mathrm{~s}^{2}$ spurred by growing needs for minerals and sovereignty concerns. France is the only country in the context of the renewed European interest for mining where mining activities had been abandoned ${ }^{3}$, including by French companies active globally, ${ }^{4}$ and were planned to be relaunched. The French 'mining revival' program was launched in 2012 in a situation where there was no mining 'present', but only memories of past activities and promises (or, for some actors, threats) of future projects. This makes the French case an exceptional site in the global landscape of mining, where the temporal politics present in all exploration activities are purified.

There is another interest in the French case, pertaining to the type of mining companies involved. While international development banks and multinational corporations often engage in mining exploring projects, only small companies specialized in exploration were involved in the French mining revival. These companies, called 'juniors' in the mining sector, are rarely analyzed by scholars of the mining controversies. ${ }^{5}$ In France, they encountered both the scepticism of local populations and the cautious support of national public bodies as they engaged in exploration projects in Brittany, the Pyrenees, and other places in the central regions of the country. They became the main actors of the state-sponsored mining revival program, which quickly abandoned an envisioned state-owned company in order to attract global private investors by stimulating and regulating exploration, and encouraging 'responsible' mining. Using this case, we will show that promise engineering is the core of what juniors do, including as they use 'responsibility' as an ingredient in the anticipation of desirable results and attempt to articulate promises addressed to different publics, whose interests are rarely convergent. We will see that the failure to ensure this articulation reveals that promise engineering defines the priorities of industrial projects in unstable ways, and eventually fuels the oppositions it is meant to tame.

\section{Promises in technical projects}

When anthropologist Stuart Kirsch (2014) used the terms 'mining capitalism', he focused on how companies conduct extraction projects by using technical and social tools that use such categories as 'science' or 'sustainability' in strategic ways. These practices can be observed in the initiatives mining companies undertake under the umbrella of 'corporate social responsibility', including as 'ethical' practices (Rajak, 2011). But the capitalist order on which mining relies also comprises another crucial component, namely financial investment. Gavin Bridge (2004) has shown how neoliberal mining policy reforms have modified established 'geographies of investment', particularly towards developing countries. Bridge also demonstrates that mining investment flows depend on variable parameters (such as the type of resource). Our analysis of promise engineering will show how, in practice, private and public actors attempt to direct mining investments in specific places. This is a challenging task since exploration is costly and risky, generates no income in its early stages, and often does not lead to the development of a mine. It is based on anticipations, which need active work to maintain the interest of investors and policy makers (Weszkalnys, 2015). Consequently, the only way to attract finance for any mining project is to provide potential investors with credible promises of future profits. 
Our analytical approach builds on science and technology studies (STS), for which mining activities have recently become a topic of interest (Kinchy et al., 2018). Two streams of STS works are particularly useful for our analysis of promises related to mining projects. First, the social studies of finance provide helpful resources, as they propose to examine how economic value and the entities being valued are constituted (Muniesa, 2011). This perspective proposes to analyse the instruments modelling future developments for economic purposes not by seeing them as more or less exact representations of a stable state of affairs, but by studying them as devices of persuasion and coordination with performative effects (Doganova \& Eyquem-Renault, 2009; Miller \& O'Leary, 2007). In the resource extraction sector in particular, recent studies of oil prospects have shown that geological and financial evaluations come together in the definition of what is profitable and what is not, thereby directly impacting the nature of the resource and how to envision its future exploitation (Shafiee, 2012; Wood, 2016). Thus, we examine the promises of future economic value as inscribed in instrumented practices facing trials of strength (Latour, 1987). We do not consider the credibility of promises as something to be assessed, but as the more or less stable outcome of processes that associate epistemic statements and normative propositions for social ordering, including about the role of the state and its citizens (Jasanoff \& Kim, 2015). This means that we consider that the evaluation of the value of promises occurs within certain social spaces, and by and for the benefit of certain actors and not others.

This perspective is particularly important when studying practices related to global financial speculation. Turning geographical spaces into sites of speculation often occurs for the benefit of global publics of investors (Goldman, 2011) or for the sake of a 'global elite' (Pow, 2011), and at the price of the exclusion of local inhabitants. In the mining sector, speculation about future projects can result in long-term consequences for those living near the exploration sites. The promises that attract investors are tied to future destructive interventions with inevitable environmental and social consequences. This is well known by mining companies and investors. A concept such as 'responsible mining' aims to anticipate, reduce or compensate the potential negative effects of extraction projects (Goodland, 2012). In the mining sector as elsewhere, 'corporate social responsibility' has become an imperative (Campbell, 2012), and we will see that the French mining revival comprised an initiative called Mine Responsable ('Responsible Mine'). What the reference to responsibility entails in the mining sector is debatable, to say the least. While responsible mining is heralded as a way to 'offer companies bigger and quicker profits, with no conflicts with surrounding communities and with fewer impacts' (Goodland, 2012, p. 2100), it is itself the target of controversies (Warnaars, 2012), draws on international norms such as 'transparency' that have their own politics (Barry, 2013), and is based on a theory of the 'responsible' subject that might conflict with other understandings of political subjectivity (Rose, 1999).

If responsibility is an ingredient in the promises related to mining projects, it also raises a number of issues: towards whom or what should mining companies be responsible? Who has the right to decide which concerns should be addressed? Can projects be stopped because they are not 'responsible' enough? These questions bring us to a second stream of STS work, which analyzes the anticipation of technological developments and policy initiatives related to 'responsibility'. STS studies of biotechnology, nanotechnology and synthetic biology have shown that the anticipation of future benefits is crucial in convincing public bodies and private companies to fund new technological domains (Frow, 2013; Laurent, 2017). This invites us to undertake an analysis of how anticipations of positive and negative impacts are crafted and by whom (Brown \& Rappert, 2017). One of the interests of this stream of STS work for our reflection in this paper is that it invites us to consider that the notion of 'responsibility' is an integral component of promise making. As the objective of 'responsible 
innovation' has become explicit in (mostly European) science policy programs (de Saille, 2015), responsibility appears less a counterweight to the dynamics of technological development than an ingredient of an 'economy of promises', within which promoters of technological development associate the reference to future benefits with the anticipation of negative consequences (Joly, 2012; Laurent, 2017; Meyer, 2015).

These two streams of STS work invite us to adopt a methodological approach that is attentive to the practical mechanisms through which promises are manufactured, and how their expected publics evaluate them (possibly in conflicting ways). They suggest that the reference to responsibility should not be taken for granted, but problematized in order to theorize the nature of promises and their publics. We follow this approach as we analyze a qualitative empirical material that comprise: a series of interviews with the actors involved in the French mining revival program (junior companies, investors, public bodies, social movements), the analysis of the relevant documentation (press material, public reports), and observations of meetings gathering some of the actors involved in the Mine Responsable initiative ${ }^{6}$. In the following, we develop our reflection on promise engineering in four steps. (1) We start by introducing the growing intervention of exploration companies in the context of shifting visions of national sovereignty in France. We then discuss how these companies attempt to convince investors (2) and public administrative bodies (3) of the value of their projects. This will lead us to examine attempts at articulating promises made to different publics, including local populations (4), and we will see that these attempts have been barely successful. We conclude by characterizing what promise engineering entails, for public and private actions now led by anticipations of future developments, and for local populations who rephrase their modes of mobilisation accordingly.

\section{From a national company to mining start-ups}

In 2012, Arnaud Montebourg, then Minister for Industrial Recovery, launched a program meant to revive mining in France. This initiative built on the work of a committee on minerals deemed 'strategic' for national sovereignty ${ }^{7}$ because of growing needs stemming from technology developments in digital and energy transition. In this context of renewed national priorities, France's geological survey office (Bureau de Recherches Géologiques et Minières BRGM) was asked to re-evaluate the country's mineral potential. The results, published in 2015, were summarised in a map of 'target areas' (See Figure 1).

\section{Insert Figure 1}

Echoing historical examples of nation-building technological programs (Hecht, 1998), Montebourg inscribed these 'target areas' in a vision of national sovereignty and international competition. In February 2014, he announced his intention to create a public company that would 're-engage France in the worldwide battle being waged by governments to gain access to natural resources' (Le Parisien, 2014). The projected Compagnie Nationale des Mines de France (CMF) was to be a new manifestation of the 'shareholder state', capable 'of contributing to strategic choices' (Le Parisien, 2014). Its shareholders would be the French state, and major French mining companies active internationally but not in metropolitan France $^{8}$. As well as providing France with independent supplies of strategic raw materials, the CMF was intended to create jobs and provide an alternative to private multinationals in foreign countries ${ }^{9}$. In the words of one of Montebourg's advisors, the CMF would 'offer an alternative based on operations that meet environmental, social, governance and wealth- 
sharing standards'. ${ }^{10}$ This aspect of the CMF was directly linked to the regulatory objective of revising France's decade-old mining code for the sake of 'sustainability'. ${ }^{11}$ Montebourg's vision for a French mining revival associated direct state interventions via a state-owned company, a strict regulatory framework in the form of a new mining code, and perspectives for future developments combining economic growth, industrial activities and measures to minimise mining's environmental and social impact. According to Montebourg, such a project was not incompatible with the involvement of private companies. Although the BRGM's geochemical inventory indicated target areas with the greatest potential for mineral exploration and exploitation, its findings had to be confirmed using additional techniques. To this end, the first exploration licenses for mainland France were granted to private companies in 2013.

These companies became the only players in the mining revival, as Montebourg's stateowned company never saw the light of day. The idea of creating the CMF was quickly shelved when Emmanuel Macron took over from Montebourg during a cabinet reshuffle on 26 August 2014, and the revision of the mining code has been lagging since then. This evolution can be read as a story of shifting sovereignty visions, from a project characterized by a direct public intervention in mining exploration to another one, where, in ways that echo the global norms of the mining sector promoted by international organisations (Campbell, 2012), the active players are private actors and the regulatory work of the state is meant to facilitate investment. This comprises turning the national territory into a mapped space of mining 'potentials' for investors to benefit from (see Figure 1) (Li, 2014).

After the end of the aborted project of a state-owned company, the task of building France's mining revival has been given to private companies that define themselves as 'the start-ups of the mining sector'. ${ }^{12}$ These companies are the so-called 'juniors', whose primary purpose is to carry out the exploration work needed to find economically viable deposits. In most cases, a junior company will not extract the minerals it finds. Rather, it will sell the mining rights to another mining company (called 'major'), which will develop the mine. Between 2013 and 2018 the French authorities granted around a dozen exploration licenses relating to a variety of mineral resources (see Table 1). As we discuss below, these companies have to convince different publics of the value of the resources they are hoping to find and of the benefits of their project. Potential investors are one of the most important of these publics.

\section{Insert Table 1}

\section{Promises for investors}

Many junior companies are small companies, often dedicated to geological prospecting. The term 'start-up' that they use points to the parallels with technology start-ups. Both types of company are based on similar economic models, rely on support from investors, and have ties with public research and expertise organizations (e.g., Variscan's French subsidiary was set up in 2010 by former BRGM geologists). A geologist and advisor to a mining company we met compared the world of mining juniors with that of biotech start-ups. They have 'the same level of capitalization and risk. 1 molecule out of 100 gives a medicine. We are in the same order of importance with mining exploration'. ${ }^{13}$ In mining as in technological innovation, start-ups must persuade potential investors of their future profitability in order to fund projects that are often costly, but may be highly profitable if they lead to exploitation. For example, Apollo Minerals invested \$5 million in the Salau deposit in the Pyrenees region, and 
announced in 2019 that it would need to invest \$25 million to complete the exploration phase. $^{14}$

Junior companies finance their exploration activities by attracting a variety of investors, including private individuals, investment funds, and larger companies (see Table 2).

Insert Table 2

In all cases, the success criterion junior companies highlight relates to investors. As the president of a junior company told us during an interview:

The return must be within 3 to 6 years... What's a return? What do I have to do? If the share price is $\$ 1$, I have to be able to give them announcements that will enable the price to go up to $\$ 2$.

Hence, a junior company's main objective is financial performance, which is measured in terms of its share price. Their hopes for the future are the same as for many other start-ups, that is, to be bought for a good price, or, alternatively, sell their mining rights. All of these operations are based on a junior company's ability to convince investors of the company's value (measured, for example, by their share price and/or the amount they are bought for), and this value is directly linked to expectations that its exploration campaigns will prove the existence of commercially viable deposits. The challenge for a junior company is to persuade investors that its exploration work may lead to the opening of a profitable mine. This happens at an early stage in the mining project. This means that the precise calculation of profitability will be undertaken at a later stage.

In the context of the French mining revival, the BRGM's mineral inventory is a crucial resource for persuading investors that exploration projects are likely to lead to profitable mines. Since the inventory allows junior companies to focus their exploration projects on areas where there is a 'potential' for extracting globally sought-after minerals (see Figure 1), it increases the credibility of the geological promises they make to investors. In other words, the inventory connects expectations for future mining operations with France's mining past. Thus, junior companies regularly refer to the inventory. For example, Scotgold Resources Ltd's 2017 annual report to investors is an illustration, among many, of the use of the mineral inventory and the history of past mining activities to prove that certain explorations would be profitable:

Most importantly, [the license] includes Les Brouzils, a small high grade open pittable antimony deposit that was discovered by the BRGM (..) during the 1970's and 1980's. According to BRGM literature (inventaire minier de la France), Les Brouzils hosts a 'geological resource' of 9,250t of antimony metal at a grade of $6,7 \% \mathrm{Sb}$ to a depth of $100 \mathrm{~m}$ and is open along strike and at depth.

However, the BRGM data are not enough to convince investors. They need to be complemented by other elements. The exploration techniques mobilized by juniors are progressive: from the least expensive to the most expensive; from the least accurate (historical data) to the most accurate (drilling). These additional operations use 'soil samples' used for 
geochemical analysis and 'aerial geophysical prospecting'. ${ }^{15}$ They provide additional data that complement the historical ones, and can be used to characterise the prospected deposits. They allow juniors to attract investors, expand the company's capital, and start drilling operations that can provide the final proofs that exploitation will be profitable (and, consequently, that the junior company and its assets are valuable). Thus, the exploration methods are knowledge production techniques and technologies of conviction directed towards investors, and, as such, elements of what we call 'promise engineering'. They are carefully articulated with each other, in ways that relate to a dual objective, namely producing geological knowledge and attracting funding. This dual dimension is clearly visible when considering drilling operations. One former junior company chairman we interviewed explained the way he conducted drilling operations, and how he organized the announcements he made to these investors about the results. He followed the same method he had used earlier when he was a geologist with the BRGM:

Exploration is 'stop or go'. If it's go, we keep going as far as we had planned; if it's stop, you have to be prepared to stop. So, if you have good results at first and then they deteriorate, what do you do? But if, on the other hand, you start bad and the results get better, you are already in better spirits and that allows you to have more resources and less risk.

This quote is illustrative of how exploration is conducted, based on decisions about whether or not to continue drilling, and on the strategic management of drilling programmes as a function of expectations of good results. It shows that the technical exploration work carried out by junior companies is closely associated with the communication aimed at investors. Making credible promises to investors is part of the technical work of the exploration project.

Promise engineering is not limited to individual exploration projects, but extend to the management of the portfolio of projects that juniors are involved in. Junior companies usually conduct several exploration projects at the same time, as a way of mitigating the important risk of failure. Table 1 shows that the junior companies active in the French mining revival all acquired several licenses, which complemented other licenses they owned in other countries. The author of the quote above acquired six licenses, and considered that only one was likely to succeed, a rate that he told us he considered 'a success'. This suggests that setting up several exploration projects also helps to influence investors' expectations. As in the case of biotechnology, multiplying exploration projects increases the chances of success but also stimulates the company's stock price.

From an investor's point of view, the junior companies operating in France are not different from other exploration companies. Yet, these junior companies insist on the advantages of the French context. They mention the availability of a recently updated mineral inventory released by the BRGM, but also the particular political context of France. This latter factor, which is widely used within financial circles (Fourcade, 2017), relates to an assessment of a country's social, political or economic characteristics in order to determine the risk involved in investing in that country. In the mining sector, an ethnographic study found that private equity companies think twice about investing in mining projects in some African countries because of their high 'political risk' (Law-Koon, 2017). Identifying geopolitical risks is a crucial issue for mining investors, who explicitly take into account the stability of the regulatory system when deciding to take part in a project (de los Reyes, 2017), in ways that build on rating and descriptive tools that can be described as "technologies of imagination" (Gilbert, 2020). The same elements are visible in France. In 2014, in a letter to his investors, the chairman of a junior company explained the company's risk strategy, and why France was 
a good choice, by explaining that the choice of France 'reduces both the exploration risk and the political risk'. ${ }^{16}$ In doing so, he formulated promises of both geological and political stability that aligned with his strategy, and which could have been different if other strategic choices had been made (such as: conducting projects in contentious political contexts, which mining companies have been doing for years, cf. Ferguson, 2005). But the association between 'exploration risk' and 'political risk' also points to another issue, directly related to the possibility to anticipate future profits, and to formulate promises accordingly. When juniors speak of the 'stability' of France, they refer both to the eventuality of major conflicts, and to what they call the 'security of mineral tenure'. This 'security' means that the exploration company is granted a legal right to extraction (which it can sell to a major company), which professionals of the mining sector wary of potential nationalizations of resources see as 'key to attracting foreign mining investment' (Morgan, 2002).

Making the promise of political stability credible is then a crucial task, for which junior companies use heterogeneous elements. The person quoted above explained to us that he 'fought to have France reintegrated into the Fraser Institute's list', which rank the most attractive country for mining investment ${ }^{17}$. He proudly told us that France reappeared on the list in 2015, thanks to the exploration projects that his company undertook across the French territory, which could 'attract many new investors'. ${ }^{18}$ He had also told us that he displayed photographs of his meetings with ministers when presenting his project to potential investors, in order to illustrate the government's support for mining operations. These arguments, qualitative if not makeshift, were largely successful in the context of the French mining revival. When we interviewed the representative of a company that invested in one of the juniors active in France, he noted government support as an important factor in the decision, comparing an earlier 'reticence to invest in France' with the new climate brought about by the mining revival initiative. His dealings with the government department responsible for mining had been, he felt, 'very positive'. ${ }^{19}$

For a geological promise to be credible it has to be associated with a social promise. In France, this promise stresses the stability of French institutions, government support to the mineral resource industry and a regulatory framework that ensures security of tenure. Although junior companies and investors explicitly highlight this social promise, they also need to convince public administrative bodies to authorize them to operate.

\section{Aligning promises to investors and promises to public bodies}

In the later phases of exploration projects when drilling is needed, junior companies can only operate when they are granted an exploration license. The office for mineral resources at the Ministry for Ecology is in charge of the process. The office's head and his deputy evaluate application dossiers sent by the companies applying for exploration licenses, and, as they told us during interviews, their main criterion for the evaluation of exploration projects is related to whether or not they are 'realistic'. What 'realistic' means is detailed in the mining regulation. Companies must provide several pieces of information and documentation in order to prove their 'technical' as well as their 'financial capabilities', ${ }^{20}$ including: details about their workforce, their past experiences in exploration and mining activities, and a technical memorandum justifying the spatial limits of the requested exploration license. They must state whether mines have been operated in the past in the zone, and the corresponding extracted quantities, the name of the operator, the operating periods etc. ${ }^{21}$ These data are not fundamentally different from what companies present to their investors. This is what the director of a junior company told us: 
I would say that what the administration is asking for is not so different from what investors are asking for [...]. Many documents and information $[\ldots]$ are things that have already been compiled [...] like maps, potential studies, inventory of former mining operations [...]. People from the administration just want to make sure that the project is serious, that we are serious too, that our investors are too, and that the project is realistic. ${ }^{22}$

Here again, the word 'realistic' points to an articulation between 'serious' technical and economic promises, able to convince both investors and civil servants that the project can indeed happen. The evaluations conducted by both groups reinforce each other. The head of the mineral resource office at the Ministry of Ecology told us that he is attentive about who the investors are. Junior companies must provide a list of shareholders who hold more than 3 per cent of the share capital, indicating the number of shares held, the status and nationality of each of the shareholders or partners. According to him, the identity of shareholders is important in order to identify actors who could be involved in various financial scandals. Conversely, obtaining an exploration license from the public administration has positive consequences at the stock exchange, and serves to attract yet other investors for future operations. $^{23}$

The alignment between promises to investors and promises to the public administration shows that ensuring that mining activities are technically and financially viable is a shared objective of both groups. A civil servant in charge of evaluating licenses told us that his work implied 'a bit of speculation'. For him, 'speculation' referred to another kind of uncertainty than that related to the accumulation of wealth. It was about the risk the state was ready to take in authorizing projects for which the economic future was uncertain, but which could create jobs and extract strategic minerals within national boundaries. His speculation aligned with that of investors, in that he saw as the expectations of future profits by the latter as a guarantee for the realization of the project. This alignment is a favourable situation for promise engineering. As other types of heterogeneous engineering (Callon, 1984; Law, 1987), it needs to re-define problems and interests so that national priorities such as job creation or strategic sovereignty can be reinscribed in the world of financial speculation.

But promise engineering also faces frictions as it needs to articulate the expectations of various publics. We will discuss examples of such frictions in the next section. To introduce them, let us consider an initiative that was meant to articulate various publics and failed to do so. Shortly after the launch of the mining revival program, the head of the mineral resource office was asked to ensure that mining companies would deal with the potential environmental and social impacts of their projects. An initiative named 'Responsible Mining' (Mine Responsable) which began with a series of meetings between government officials, representatives from the French mining industry, environmental groups and experts from research institutions. During these meetings, various topics were discussed, such as environmental impacts or rehabilitation. The overall objective was to draw up a white paper that would set out good mining practices and include a soft law charter for private companies. These good practices were intended to guarantee certain quality standards for mining operations, and would be based on private international initiatives, such as the International Council on Mining and Metals principles, or the principles of the Initiative for Responsible Mining Assurance (IRMA), which comprise such objectives as: 
respect the rights and aspirations of affected communities; provide safe, healthy and respectful workplaces; avoid or minimize damage to the environment; leave a positive legacy. ${ }^{24}$

When we met him, the head of the mineral resource office noted that the launch of Mine Responsable coincided with the first serious local oppositions to exploration projects, especially in Brittany, where Vigil'oust, one of the largest pressure groups, was formed at the beginning of 2015. This is more than a mere coincidence. Considering that the overall low political risk of France was a central element used by junior companies to convince their investors that geological promises could translate into feasible projects, the all too visible opposition movements threatened to make investors wary. Accordingly, the Mine Responsable initiative quickly focused on the issue of 'social acceptability', ${ }^{25}$ in the words of the head of the mineral resource office. The expression was meant to articulate promises made to three groups of public. First, investors needed to be reassured that mining projects would be conducted in such ways that they would be 'acceptable', and therefore not stopped because of local opposition. Second, the public administration would complement its assessment of the 'realistic' character of the project by ensuring that it had the potential to be well integrated in local communities. Third, the local populations living close to the mining sites would accept the projects because it would benefit from positive economic impacts, while trusting mining companies to mitigate potential negative environmental effects.

This ideal version of 'social acceptability' was never realized, and the Mine Responsable initiative did not remain consensual for long. Initially intended to gather companies, public bodies and environmental groups, it quickly faced criticisms. In the meetings that we observed, the representatives of France Nature Environment, a federation of French environmental protection groups, and Systext, an activist group focusing on mineral resources, repeatedly raised the issue of the control of voluntary 'good practices'. They interpreted Mine Responsable as a clumsy attempt to follow voluntary international norms instead of revising the French decade-old mining code in which only limited environmental constraints existed. On 16 September, 2015, the meeting started with a formal statement by the two NGO representatives, who stated that their concerns had not been answered, and that they withdrew their support for and participation in the Mine Responsable initiative ${ }^{26}$.

This episode is particularly important for our reflection on the engineering of promises and the various publics to which they are addressed. It illustrates a disconnect between the geological and political promises needed to convince investors, and the social and environmental promises needed to win over communities potentially impacted by mining projects. We explore this disconnect in more details in the next section, starting with the local opposition to the projects of the French mining revival program.

\section{Conflicting promises}

As the Mine Responsable meetings were organized, the opposition to exploration projects was increasing. Residents' associations and environmental groups had been opposing new mining exploration projects in mainland France since 2015. The most vocal ones have been Vigil'oust, opposed to the Merleac project in Brittany, Douardi Doull, opposed to the LocEnvel project also in Brittany, and Stop Mine Salau, opposed to a project conducted in Salau, in the Pyrenees. The reasons for this opposition are diverse. In Brittany, the opposition to mining is often related to the scars left by earlier mining exploration projects, such as the drilling the BRGM carried out at Portes-aux-Moines, near Merleac, when drawing up the 
mining inventory in the late 1970s. In the Pyrenees, the area's mining past is itself a controversial subject. Environmental groups and local residents have been contesting the mining project on the basis of the old mine's negative environmental and alleged health impacts, whereas other groups support reopening the mine, and present it as a new regional development project. While the mining revival program was meant to reposition France in the global landscape of mineral exploration and extraction, the idea of 'revival' conjured up other references for opponents of mining projects. They engaged in another politics of time, which did not refer to past mines as signs of extraction potential as juniors do, but claimed that future prospects of extraction had to include considerations about past mining activities, how they still had impacts or had been replaced by other activities. 'Talking about the aftermath is a starting point for any discussion about future projects', said a representative of a French NGO that withdrew from the Mine Responsable initiative, by which she meant that dealing with the consequences of the past was necessary for making any promise about potential mining futures credible.

Demonstrations of various types and threats to obstruct drilling then became commonplace. Some opponents adopted radical forms of protest, as a homemade bomb exploded at Variscan's head office in Orleans on 23 May 2016 and a few months later an explosive device was found on one of the company's drill rigs. Although the immediate targets of these actions were exploration projects, the ultimate aim was to prevent any possible future mining operations, which opponents saw as being ineluctably linked to exploration. An opponent we met explained this connection in those terms:

The pro-mining argument is 'we have to drill before making any decisions; afterwards, we'll see. There's no risk in taking a core sample'. But if the Australians are here, it's because there's potential here [...] It's not us saying that, it's them, it's the BRGM, it's the government, and all they say to us is 'don't worry it's just a few little holes'. But if they prove there is gold, or I don't know what, the spiral begins. [Juniors] say so themselves; there is great potential. What we are blocking is the mining project that we haven't got to yet ${ }^{27}$

This quote highlights the discrepancies that opponents perceive between two discourses. On the one hand, companies try to reassure local communities worried about the impact of possible mining operations by stating that drilling a core sample does not necessarily imply a future exploitation project (an exploration project is 'just exploration'). On the other hand, they seek to convince their investors that 'there is great potential', as they stress the likelihood that they will discover economically viable deposits.

This contradiction is the result of the junior companies trying to formulate promises that will satisfy publics with different expectations, and with concerns that span different timescales. Junior companies have relatively short-term goals, which focus on the need to discover economically viable deposits so that the company and/or the mining rights it holds can be sold at a profit. This short-term focus clashes with the long-term concerns of local communities, who worry about the possible negative impacts of any future mining operations that may last over decades. For these local communities, the central role of financial investment in mining exploration also provides a strong incentive to demonstrate to the investors that the promise of social stability is not credible. If seen from the viewpoint of the opponent to the mining project, staging spectacular protests (like the makeshift bomb) may be the best way of demonstrating to the exploration companies' investors that social acceptability is not 
guaranteed. Thus, promise engineering is a technical and economic organization of industrial activities, that, as other material arrangements of extraction (Mitchell, 2011), is tied to specific forms of social mobilization, namely those that connect spectacular interventions with anticipations of long-term consequences fuelled by past experiences.

This makes promise engineering a daunting task, which is well perceived by the companies themselves, as they face both investors wary of too visible social opposition, ${ }^{28}$ and opponents who contest future projects on which exploration companies have few levers by staging visible demonstrations (Barry, 1999). A geologist working for a junior company in Brittany told us that he was regularly asked about possible future exploitation projects. He saw the contradictions between the expectations of the company's various publics as problematic because of junior companies' inability to make commitments about future mining operations. $^{29}$ While major companies conducting exploitation projects have been using 'corporate social responsibility' (CSR) following more or less standardized norms, juniors can only formulate hypothetical commitments depending on an uncertain geological potential. In doing so, they have to invent original approaches to responsibility.

We can come back at this stage to 'promise engineering'. We introduced this term to characterize the operations whereby junior companies integrate technical and social promises meant to convince investors and public bodies in the conduct of their exploration projects. But we also refer to promise engineering to point to the work junior companies undertake when they attempt to reconcile their various publics and the promises they offer them. A first attempt to do so is based on 'commitments' designed to accommodate different expectations. For instance, Apollo Minerals had been trying to overcome the opposition against its exploration project in the Pyrénées by committing itself to follow a code of 'good conduct' about how any future mine would be operated, drawn largely from the white paper produced under the Mine Responsable initiative. Alongside these commitments, the company set up the Club de Mécènes des Mines du Salat (CMMS - Salat Mines Benefactors Club) in June 2018 in order to help restore the area's cultural heritage. These measures were not aimed uniquely at local communities. They had also been used to reassure investors who may have been concerned about the impact of local oppositions to the project. Thus, in July 2018 Apollo Minerals used an announcement to the Australian Stock Exchange, where the company is listed, to tell investors how the company 'is showing its commitment to local communities'. ${ }^{30}$ It illustrated this commitment by presenting the CMMS, which it described as an initiative that would generate 'benefits for all stakeholders' and help the company fulfil its 'duty to ensure that its social, environmental and economic impact is positive'.

In doing so, Apollo Minerals tried to align the expectations of various publics by drawing on the objective and practice of 'responsibility'. The objectives of its commitments to the local community were to reassure local inhabitants and to address one of the main criticisms of the project - the difficulty of reconciling mining operations with tourism. The company attempted to appeal to the collectives, composed mainly of retired former miners and trade unionists, that had voice support for the project, and to show to investors that the project was indeed accepted by the local community (or at least some of it). But commitments such as those proposed by Apollo Minerals have remained uncertain at best, because of the speculative future of exploration projects. Opponents have challenged the credibility of promises about long-term consequences as most junior companies will leave way to other companies after the exploration phase. More fundamentally, the uncertainty about commitments has to do with the conflicting ways of reasoning about the future in temporal and spatial terms. While those expected to benefit from the commitments evaluate them according to their long-term anticipations about a singular geographical site (the one they inhabit), juniors manage a portfolio of projects in various places, and conduct their projects in 
relation with each other. They would be reluctant to abandon a project, even if they know it has little chance to be realized, for fear of sending negative signals to investors. Thus, they can discuss potential commitments with local populations who could send such negative signals, even though they are themselves sceptical about the realization of the project.

Another junior company adopted a different approach, which illustrates another attempt at aligning conflicting expectations. SUDMINE is an independent French company that raised its capital from a variety of shareholders (see Table 2). While it proposed commitments about future mining operations like other juniors, the company also actively encouraged local populations to invest in the company. To this end, it published a brochure in which it described the project's 'participative' economic model. One of the company's objectives is 'to open up the capital of the future operating company to individuals, companies and local and regional (extended to the Basque Country) bodies'. ${ }^{32}$ SUDMINE presented their approach, which they likened to a form of crowdfunding, in public meetings. They listed the expected benefits as follows:

Crowdfunding - Why is it interesting for mining projects:

- involving local populations

- creating incentives for local compensations

- participating in financing exploration

- participating in financing exploitation

- freeing the project from banks (or completing them)

- following a contemporary trend

- modernizing the mine's public image

- $\quad$ ensuring the re-birth of the dream of the gold mine ${ }^{33}$

SUDMINE used this heterogeneous list of arguments in its application dossier sent to the public administration as well. Here, aligning promises and their publics consisted in turning local populations into investors. The quotes above describes a form of public participation in mining projects that is supposed to ensure both the realization of 'compensations' and a somewhat unclear modern and attractive 'image' of the mine. This list is not specific about the relations between different investors, and the resolution of potential conflicts between them ('freeing the project from banks' or 'complementing them' might have very different consequences). This might be the reason why crowdfunding was never more than a proposition, which eventually failed to convince both the national public administrative bodies that their project was realistic enough to be granted a license, and local opposition movements that they could meaningfully participate in the project. Rather than accepting to transform their reasoning about the future to make it a matter of financial speculation, opponents to SUDMINE staged protests explicitly addressed to investors and questioned the uncertain nature of the project's financing. In a press release, they stated that the company 'did not have a viable financing plan' and considered it useful 'to show the opposition to this project to future investors'. 34

Both Apollo's charter and SUDMINE's participatory financing were attempts at aligning the promises made to investors with those made to local opponents. These approaches have been barely successful. The reason for these failures is profound. Exploration companies act in the 
present for the sake of a speculative future, defined by the calculation of financial benefits and the risks facing them across a portfolio of projects, and displayed in promises made to investors. The opponents of mining projects connect past consequences with anticipations of future consequences that are not necessarily framed in the language of risks, and which are tied to the places they inhabit. Oppositions occur not just about the time frame of certain initiatives, but about the very way of problematizing the future.

\section{Conclusion}

How are expectations about the future of industrial projects constructed and to whom are they credible? We have argued that analyzing how the actors of mining projects answer these questions offer a productive path to understand the relationships between companies and the actors they interact with, including those who are opposed to them. The notion of 'promise engineering' can be used to describe the operations companies use to formulate promises and integrate them in industrial projects, and to articulate promises made to different publics. In the mining exploration sector, these promises are both technical and social. Although they are primarily aimed at convincing investors, other promises are made to public bodies and local communities. As we showed in the previous section, formulating promises that will convince all their different publics is a difficult task, and opponents find levers of action in promise engineering, as they staged demonstrations that display the elusiveness of the promise of social stability. Promise engineering is a type of 'social engineering', not in the sense that companies would only intervene on social behaviours, but in that they integrate social considerations in the promise they address to investors, public bodies, and local populations, while also seeking to align the interests of various publics.

France has provided a telling illustration of promise engineering in the world of mining exploration. Promise engineering is conducted in different terms in other contexts, where international development investors such as the World Bank are active, global extraction companies routinely use corporate social responsibility tools that public bodies are familiar with, and indigenous populations raise additional issues. Promise engineering is not specific to the French 'mining revival' and we could also analyze elsewhere how companies integrate promises in the technical management of their projects, and attempt to articulate promises made to different publics. But it is particularly easy to analyze it in France, as public companies, mining companies and their opponents associate the past and the future of mining activities while no present project exists. This results in a situation whereby the state's position in relation to global investment is uncertain, as public bodies shift from a state-led vision to the promotion of privately-led exploration projects, build on the regulatory capacities of a developed state, yet attempt to draw on international norms to complement a mining code that has not been revised for years with a voluntary initiative.

Perhaps because of its specificities, the French case has helped us identify what promise engineering entails. It is part of an economic system based on investment. Here, responsibility is less a counterbalance to the forces of speculation than an integral component of an economy based on investment, which is always in search of reassurance that the technical and social conditions for exploitation will be met. Thus, we saw that the Mine Responsable initiative, which echoes a wider interest in responsible mining, is perfectly coherent with promise engineering. The paradoxical consequence is that this initiative does little to soothe the opposition to mining projects since promise engineering invites opponents to undermine the credibility of the promises of social acceptability made to investors by staging spectacular demonstrations. 
The case of the French mining revival also shows that promise engineering can be more or less open to rearrangements. The initial project of a state-owned company envisioned promises made by the state to its inhabitants, and possibly to partners abroad where the company would have also operated. This initial project can be seen as another configuration for engineering promises, which is state-led instead of being based on financial speculation, and offers another articulation between economic organizations, technical developments and state sovereignty, or, in Gabrielle Hecht's (1998) terms, another technopolitical regime. As they contest speculation practices by staging protests addressed not only to the junior companies themselves but also to their potential investors, opponents to mining projects engage in counter-practices that turn promise engineering upside down. They contest the temporal validity of the commitments proposed by exploration companies, anticipate future consequences by drawing on past events, and demonstrate that mining activities, however responsible they are, will have a social cost for investors. They claim that the temporal and spatial connections that juniors draw on need to be debated, and in doing so, they open up the temporal and spatial politics of industrial projects.

Thus, the analysis of promise engineering offers both an analytical lens for studying anticipation practices in industrial projects, and a channel for political interventions in or against these projects. The mining sector is not the only domain where investors play crucial roles, where the discourse of responsibility is more and more present, and where local concerns and the global dynamic of financial investment are in tension. In these situations, the study of the practices and consequences of promise engineering can be a way of identifying the sources of social conflicts, and, more generally, how future technical developments are expected to benefit certain social groups, possibly at the expense of others.

\section{Acknowledgements}

A previous version of this paper was presented at the 2019 conference of the Association Française de Science Politique. We thank the reviewers and editors for their comments and suggestions.

\section{Funding statement}

Part of the empirical research on which this paper is based was funded by Région Lorraine and the French National Research Agency (ANR) (ANR-10-LABX-21-01, LABEX RESSOURCES21).

\section{Disclosure agreement}

No potential conflict of interest was reported by the authors.

\section{References}

Barry, A. (1999) Demonstrations: Sites and sights of direct action. Economy and Society, 28(1), 75-94.

Barry, A. (2013) Material politics: Disputes along the pipeline. John Wiley \& Sons. 
Bowker, G. (1994). Science on the run: Information management and industrial geophysics at Schlumberger. MIT Press.

Bridge, G. (2004). Mapping the bonanza: Geographies of mining investment in an era of neoliberal reform. The Professional Geographer, 56(3), 406-421.

Brown, N. \& Rappert, B. (2017). Contested futures: A sociology of prospective technoscience. Routledge.

Callon, M. (1984). Some elements of a sociology of translation. The Sociological Review, 32(1), 196-233.

Campbell, B. (2012). Corporate social responsibility and development in Africa. Resources Policy, 37(2), 138-143.

Doganova, L.; \& Eyquem-Renault, M. (2009). What do business models do?- Research Policy, 38(10), 1559-1570.

de los Reyes, J. A. (2017). Mining shareholder value: Institutional shareholders, transnational corporations and the geography of gold mining. Geoforum, 84, 251-264.

De Saille, S. (2015). Innovating innovation policy: The emergence of 'responsible research and innovation'. Journal of Responsible Innovation, 2(2), 152-168.

Dougherty, M. L. (2011). The global gold mining industry, junior firms, and civil society resistance in Guatemala. Bulletin of Latin American Research, 30(4), 403-418.

Ferguson, J. (2005). Seeing like an oil company: Space, security, and global capital in neoliberal Africa. American Anthropologist, 107(3), 377-382.

Fourcade, M. (2017). State metrology: The rating of sovereigns and the judgment of nations. In K. Morgan \& A. Orloff (Eds.), The many hands of the state (pp. 103-127). Cambridge University Press.

Frow, E. K. (2013). Making big promises come true? Articulating and realizing value in synthetic biology. BioSocieties, 8(4), 432-448.

Geenen, S. (2018). Underground dreams: Uncertainty, risk and anticipation in the gold production network. Geoforum, 91, 30-38.

Gilbert, P. R. (2020). Speculating on sovereignty: 'money mining'and corporate foreign policy at the extractive industry frontier. Economy and Society, 49(1), 16-44.

Goldman, M. (2011). Speculative urbanism and the making of the next world city. International Journal of Urban and Regional Research, 35(3), 555-581.

Goodland, R. (2012). Responsible mining: The key to profitable resource development. Sustainability, 4(9), 2099-2126.

Hecht, G. (1998). The radiance of France: Nuclear power and national identity after World War II. MIT Press.

Hecht, G. (2012) Being nuclear: Africans and the global uranium trade. MIT Press.

Jasanoff, S. \& Kim, S.H. (Ed.). (2015). Dreamscapes of modernity. Chicago University Press.

Joly, P.B. (2012). Innovation 'responsable' et développement durable: Produire la légitimité des OGM et de leur monde. Futuribles, 383, 89-110.

Kinchy, A. J., Phadke, R., \& Smith, J. M. (2018). Engaging the underground: An STS field in formation. Engaging Science, Technology, and Society, 4, 22-42. 
Kirsch, S. (2014). Mining capitalism: The relationship between corporations and their critics. University of California Press.

Latour, B. (1987). Science in action. Harvard University Press.

Laurent, B. (2017). Democratic experiments: Problematizing nanotechnology and democracy in Europe and the United States. MIT Press.

Law, J. (1987). Technology and heterogeneous engineering: The case of Portuguese expansion. In W. E. Bijker, T. P. Hughes \& T. Pinch (Eds), The social construction of technical systems (pp. 111-134). MIT Press.

Law-Koon, H. (2017). La décision d'investissement en private equity minier (Unpublished research report). Mines ParisTech.

Le Parisien. (2014, February 21). La renaissance d'une compagnie nationale des mines.

Li, T. (2014). What is land? Assembling a resource for global investment. Transactions of the Institute of British Geographers, 39(4), 589-602.

Majury, N. (2014). 'Trusting the numbers': Mineral prospecting, raising finance and the governance of knowledge. Transactions of the Institute of British Geographers, 39(4), 545558.

Meyer, M. (2015). Devices and trajectories of responsible innovation: Problematising synthetic biology. Journal of Responsible Innovation, 2(1), 100-103.

Miller, P., \& O'Leary, T. (2007). Mediating instruments and making markets: Capital budgeting, science and the economy. Accounting, Organizations and Society, 32(7-8), 701734.

Mitchell, T. (2011). Carbon democracy. Verso Books.

Morgan, P. G. (2002). Mineral title management: The key to attracting foreign mining investment in developing countries?- Applied Earth Science, 111(3), 165-170.

Muniesa, F. (2011). A flank movement in the understanding of valuation. The Sociological Review, 59, 24-38.

Rajak, D. (2011). In good company: An anatomy of corporate social responsibility. Stanford University Press.

Rose, N. (1999). Powers of freedom. Cambridge University Press.

Pow, C. P. (2011). Living it up: Super-rich enclave and transnational elite urbanism in Singapore. Geoforum, 42(3), 382-393.

Shafiee, K. (2012). A petro-formula and its world: Calculating profits, labour and production in the assembling of Anglo-Iranian oil. Economy and Society, 41(4), 585-614.

Tsing, A. L. (2011). Friction: An ethnography of global connection. Princeton: Princeton University Press.

Warnaars, X. S. (2012). Why be poor when we can be rich? Constructing responsible mining in El Pangui, Ecuador. Resources Policy, 37(2), 223-232.

Weszkalnys, G. (2014). Anticipating oil: The temporal politics of a disaster yet to come. The Sociological Review, 62, 211-235.

Weszkalnys, G. (2015). Geology, potentiality, speculation: On the indeterminacy of first oil. Cultural Anthropology, 30(4), 611-639. 
Wood, C. L. (2016). Inside the halo zone: Geology, finance, and the corporate performance of profit in a deep tight oil formation. Economic Anthropology, 3(1), 43-56.

\section{Authors' biographies}

Julien Merlin is a Postdoctoral Researcher at PACTE (UMR 5194). His work in anthropology and sociology of science and technology focuses on activities related to the underground (mining, geothermal energy, geology). He wrote his $\mathrm{PhD}$ thesis (The mining trial: Indigenous people and the environment in the New Caledonian mining sector) at the Centre de Sociologie de l'Innovation (Mines ParisTech, PSL University).

Brice Laurent is a Researcher at the Center for the Sociology of Innovation (Mines ParisTech, PSL University), and works on the relationships between technical projects and democratic ordering. $\mathrm{He}$ is the author of Democratic experiments: Problematizing nanotechnology and democracy in Europe and the United States (2017, The MIT Press), European objects: The troubled dreams of harmonization (forthcoming, The MIT Press), and co-editor, with Alexandre Mallard, of Labelling the economy: Qualities and values in contemporary markets (2020, Palgrave).

Yann Gunzburger is a Professor in Applied Geosciences at the GeoRessources laboratory, Université de Lorraine, France. His research topics range from mining engineering and the associated risk analysis, to the study of interactions between extractive industries and territorial dynamics in various countries, including France, French Guiana and Guinea.

\section{Notes}

\footnotetext{
${ }^{1}$ Press release issued by Vigil'oust and AttentionMines on 17 April 2018.

${ }^{2}$ See for instance the European 2008 'Raw materials initiative'.

${ }^{3}$ In 2017 among the 74 metallic mines active in Europe, none was located in France's European territory.

${ }^{4}$ There are active mining sites in overseas France, particularly New Caledonia and French Guiana. French mining companies have been active in various countries (Bowker, 1994; Hecht, 2012).

${ }^{5}$ See however (Dougherty, 2011; Majury, 2014).

${ }^{6}$ All actors interviewed were informed of our research objectives. We presented our results to some of the interviewees.

${ }^{7}$ This Comité pour les Métaux Stratégiques gathers civil servants and business actors.

${ }^{8}$ Orano Mining and Eramet. The French State is a significant shareholder in these two companies.

${ }^{9}$ ibid

${ }^{10}$ Interview of Raphael Keller by the French Geological Society, 15 May 2014.

${ }^{11}$ Speech of Arnaud Montebourg, 16 October 2012.

12 These terms were used in our interviews.

${ }^{13}$ Interview, Paris, 5 April 2019.

${ }^{14}$ La Dépêche, Mine de Couflens: Apollo minerals va investir 25 millions, 6 June 2019.
} 
${ }^{15}$ Interview, Paris, 8 June 2018.

${ }^{16} 2014$ ASX report of a junior operating in France.

17 See Fraser Institute Report https://www.fraserinstitute.org/sites/default/files/survey-of-mining-companies2015.pdf

18 Interview, Paris, October 2018.

${ }^{19}$ Interview, Paris, 7 June 2018.

${ }^{20}$ See Decree $\mathrm{n}^{\circ} 2006-648$ du 2 juin 2006 relatif aux titres miniers et aux titres de stockage souterrain [Decree $\mathrm{n}^{\circ} 2006-648$ of 2 June 2006 relative to mining titles and underground storage titles]

${ }^{21}$ Ibid.

${ }^{22}$ Interview, Paris, 1 June,-2017.

${ }^{23}$ See Variscan's ASX announcement on 10 November 10, 2004, 'Variscan secures the Merléac exploration license'.

${ }^{24}$ https://responsiblemining.net/wpcontent/uploads/2018/07/IRMA_STANDARD_v.1.0_FINAL_2018.pdf

${ }^{25}$ Interview, Paris, 13 November 2016.

${ }^{26}$ One of us attended this meeting.

${ }^{27}$ Interview, Guingamp, April 2018.

${ }^{28}$ The chairman of a junior told us that investors might 'get tired' because of social opposition. Interview, Orléans, January 2018.

29 Interview, Paris, April 2018.

${ }^{30}$ Apollo Minerals demonstrates commitment to local communities, ASX announcement, 19 July 2018.

${ }^{31}$ Ibid.

32 'Kanbo exploration project: Winning back Basque Gold', SUDMINE internal document.

${ }^{33}$ Extract from SUDMINE public presentation (19 May; 2015), translated from the French.

${ }^{34}$ Press release (7 February 2017) of local organizations comprising farmers' organizations and environmental protection groups. 


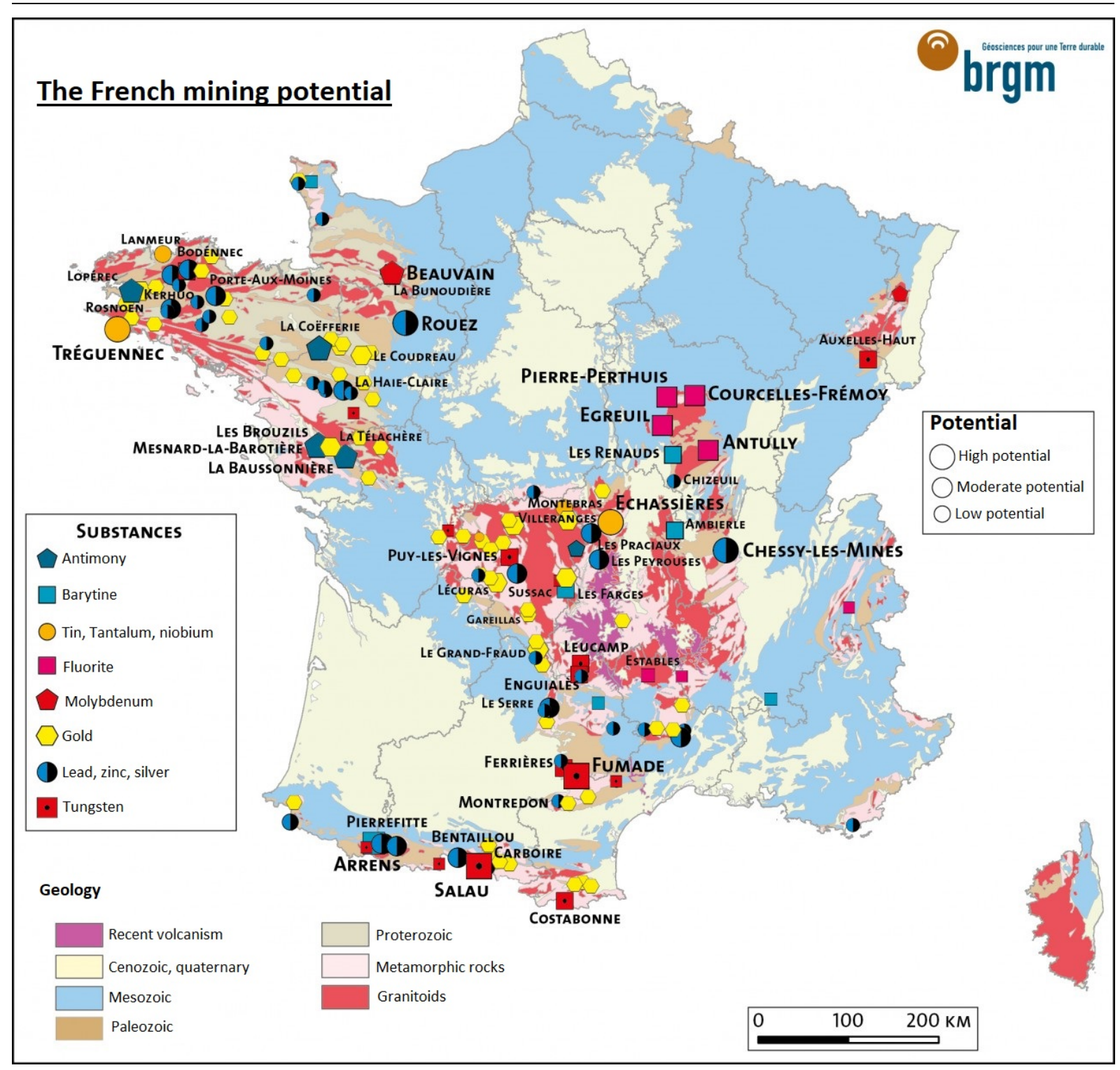

Figure Erreur! Document principal seulement. The French mining potential

Source: BRGM, our translation 


\section{Table 1 Junior companies in France}

\begin{tabular}{|c|c|c|c|}
\hline $\begin{array}{l}\text { Examples of mining } \\
\text { exploration } \\
\text { companies operating } \\
\text { in France (juniors) }\end{array}$ & Overview & $\begin{array}{l}\text { Mining exclusive research } \\
\text { permit (MERP) location } \\
\text { requested by juniors }\end{array}$ & $\begin{array}{l}\text { Examples of substances } \\
\text { that juniors looking for }\end{array}$ \\
\hline $\begin{array}{l}\text { Platsearch NL, } \\
\text { Variscan Mines Ltd } \\
\text { and Variscan SAS } \\
\text { France }\end{array}$ & $\begin{array}{l}\text { Variscan Mines Ltd is an ASX listed } \\
\text { Australian resource company focused on } \\
\text { exploring mineral deposits. The company was } \\
\text { incorporated in } 1987 \text { (as PlatSearch NL). } \\
\text { Variscan France SAS is the local subsidiary } \\
\text { of the Australian junior Variscan Mines } \\
\text { Limited. }\end{array}$ & $\begin{array}{l}\text { Tennie (2013); Merleac } \\
\text { (2014); Saint Pierre (2014); } \\
\text { Beaulieu (2015); Silfiac } \\
\text { (2015); Loc-Envel (2015); } \\
\text { Couflens (2017) and other } \\
\text { project in Europe and the } \\
\text { world }\end{array}$ & $\begin{array}{l}\text { Gold, copper, silver, zinc, } \\
\text { antimony, tin, tungsten } \\
\text { and related substances }\end{array}$ \\
\hline $\begin{array}{l}\text { Apollo Minerals Ltd } \\
\text { and Mine Du Salat }\end{array}$ & $\begin{array}{l}\text { Apollo Minerals is an exploration company } \\
\text { listed on the Australian Stock Exchange } \\
\text { (ASX). In June 2018, the government } \\
\text { authorized Apollo Minerals to acquire } \\
\text { Variscan Mines SAS and its MERP. } \\
\text { Mine du Salat is the local subsidiary of } \\
\text { Apollo Minerals. }\end{array}$ & $\begin{array}{l}\text { Couflens (2018) and several } \\
\text { others in Europe }\end{array}$ & Tungsten and gold \\
\hline $\begin{array}{l}\text { Scotgold Resources } \\
\text { Ltd and SGZ France }\end{array}$ & $\begin{array}{l}\text { Scotgold Resources Ltd is a compagny listed } \\
\text { on the AIM, London Stock Exchange. The } \\
\text { junior presents itself as a specialist in gold } \\
\text { exploration in territories with low risk } \\
\text { juridictions. The company is developing } \\
\text { several projects in Europe. }\end{array}$ & $\begin{array}{l}\text { Olivet (2015), Vendrennes } \\
\text { (2017) and several others in } \\
\text { Europe }\end{array}$ & Gold and silver \\
\hline $\begin{array}{l}\text { Montezuma Mining } \\
\text { Company Ltd and } \\
\text { Cordier Mines SAS }\end{array}$ & $\begin{array}{l}\text { Montezuma Mining Company Ltd is a junior } \\
\text { company listed on the ASX. (Recently } \\
\text { renamed Element 25). Cordier Mines SAS is } \\
\text { its local subsidiary in France. }\end{array}$ & $\begin{array}{l}\text { Penlan (2014) } \\
\text { Bonneval (2017) and several } \\
\text { other around the world }\end{array}$ & Gold and silver \\
\hline SUDMINE & $\begin{array}{l}\text { A mining company incorporated under } \\
\text { French law in January 2013. It is the only } \\
\text { local company that is not linked to a foreign } \\
\text { junior and to foreign capital. }\end{array}$ & $\begin{array}{l}\text { Loperec (2), Kanbo and } \\
\text { several others in French } \\
\text { Guyana }\end{array}$ & $\begin{array}{l}\text { Gold, copper, silver, zinc, } \\
\text { antimony, tin, tungsten } \\
\text { and related substances }\end{array}$ \\
\hline $\begin{array}{l}\text { La Mancha Resources } \\
\text { Ltd and Cominor }\end{array}$ & $\begin{array}{l}\text { Cominor est une société minière possédée par } \\
\text { La Mancha Resources Ltd. }\end{array}$ & Villegrange (2013) & $\begin{array}{l}\text { Gold, copper, silver, zinc, } \\
\text { antimony, tin, tungsten } \\
\text { and related substances }\end{array}$ \\
\hline $\begin{array}{l}\text { Raubex Group Ltd } \\
\text { and Tungstène du } \\
\text { Narbonnais }\end{array}$ & $\begin{array}{l}\text { Raubex is a South African company, with a } \\
\text { division dedicated to mining exploration. } \\
\text { Tungstène du Narbonnais is its French } \\
\text { subsidiary, dedicated to exploring in France. }\end{array}$ & $\begin{array}{l}\text { Fabrié (2018) and other } \\
\text { exploration project around the } \\
\text { world, particularly in Africa }\end{array}$ & $\begin{array}{l}\text { Tungsten, gold, bismuth, } \\
\text { tin, Molybdène, zinc, } \\
\text { cuivre, indium, scandium } \\
\text { and related substances }\end{array}$ \\
\hline
\end{tabular}

Source: Compiled by authors 
Table 2 Junior companies and their main investors

\begin{tabular}{|c|c|c|}
\hline Juniors & $\begin{array}{c}\text { Capital } \\
\text { structuration }\end{array}$ & Investors \\
\hline $\begin{array}{l}\text { PlatSearch / } \\
\text { Variscan Mines } \\
\text { Ltd } \\
\text { (Australia) }\end{array}$ & $\begin{array}{l}\text { Junior listed on the } \\
\text { ASX (Australian } \\
\text { Securities } \\
\text { Exchange) }\end{array}$ & $\begin{array}{ll}\text { Main investors in 2014: } \\
\begin{array}{cl}\text { - } & \text { HSBS Custody Nominees Ltd (Bank, Australia) } \\
\text { - } & \text { UOB KAY HIAN Private Ltd (Investment banking, Singapore) } \\
\text { - } & \text { Mrs Chris Carr \& Mrs Betsy Carr (Private individuals, Australia) } \\
\text { - } & \text { Minotaur Resources investments Pty Ltd (The subsidiary of a junior company, Australia) } \\
\text { - } & \text { DBS Vickers Securities (Investment banking, Singapore) } \\
\text { - } & \text { Mr Xiangjun Zhang (Private individual, Singapore) } \\
\text { - } & \text { Warman Investments Pty Ltd (Investment banking, Australia) }\end{array}\end{array}$ \\
\hline $\begin{array}{l}\text { Apollo Minerals } \\
\text { (Australia) }\end{array}$ & $\begin{array}{l}\text { Junior listed on the } \\
\text { ASX (Australian } \\
\text { Securities } \\
\text { Exchange) }\end{array}$ & $\begin{array}{cl}\text { Main investors in 2018: } \\
\begin{array}{cl}\text { - } & \text { HSBC Custody Nominees Ltd (Bank, Australia) } \\
\text { - } & \text { Citicorp Nominees Pty Ltd (Investment banking, Australia) } \\
\text { - } & \text { Juniper Capital Partners Ltd (Private investment fund, London, Dubaï and Singapore) } \\
\text { - } & \text { Arredo Pty Ltd (Private investment fund, Australia) } \\
\text { - } & \text { Australia Nominees Pty Ltd (provides nominee and other custody services for securities } \\
& \text { market in Australia) } \\
\text { - } & \text { Zero Nominees Pty Ltd (Australia) } \\
\text { - } & \text { AWJ Family Pty Ltd (Australia) } \\
\text { - } & \text { Pershing Australia Nominees Pty Ltd (Australia) } \\
\text { - } & \text { J.P. Morgan Nominees Australia Ltd } \\
\text { - } & \text { Mr Mark Stuart Savage (Private individual, Australia) } \\
\text { - } & \text { Mr Robert Arthur Behets \& Mrs Kristina Jane Behets (Private individuals) }\end{array}\end{array}$ \\
\hline $\begin{array}{l}\text { Scotgold } \\
\text { Resources Ltd } \\
\text { (Australia/United } \\
\text { Kingdom) }\end{array}$ & $\begin{array}{l}\text { Junior listed on the } \\
\text { London Stock } \\
\text { Exchange (On the } \\
\text { Alternative } \\
\text { Investment } \\
\text { Market) }\end{array}$ & $\begin{array}{l}\text { Main investors in 2018: } \\
\begin{array}{cl}\text { - } & \text { Mr Nat le Roux (Chairman of Scotgold Resources) } \\
\text { - } & \text { Computershare Clearing Pty Ltd (Stock transfer company, Australia) } \\
\text { - } & \text { Golden Matrix Holdings Pty Ltd (Investment banking, Australia) }\end{array}\end{array}$ \\
\hline $\begin{array}{l}\text { Montezuma } \\
\text { Mining } \\
\text { Company / } \\
\text { Element } 25 \\
\text { (Australia) }\end{array}$ & $\begin{array}{l}\text { Junior listed on the } \\
\text { ASX (Australian } \\
\text { Securities } \\
\text { Exchange) }\end{array}$ & 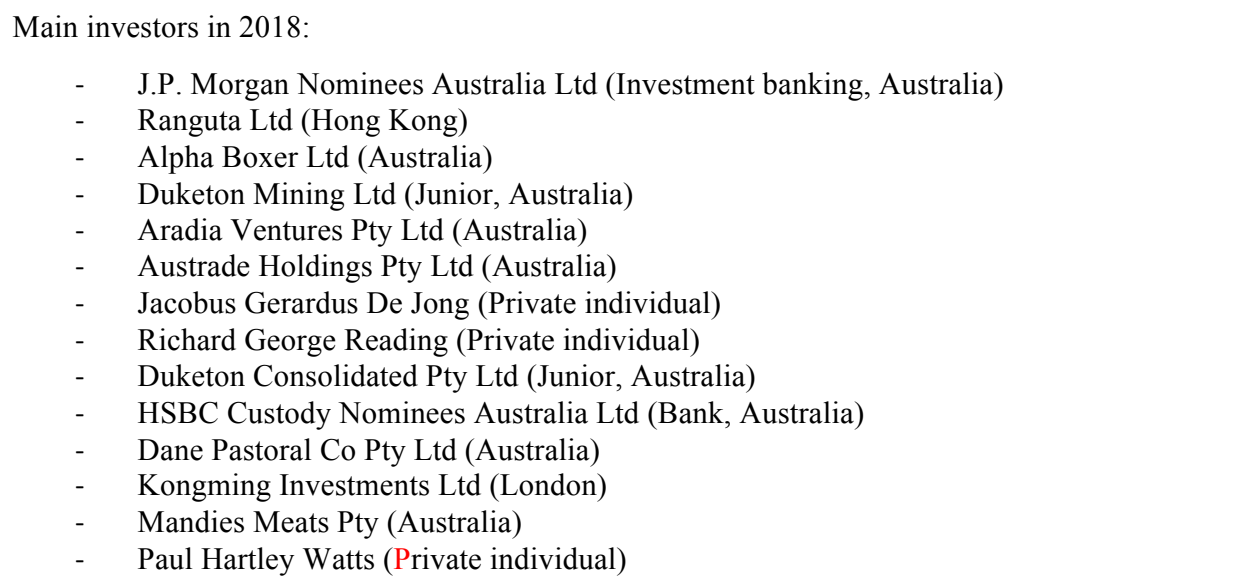 \\
\hline
\end{tabular}




\begin{tabular}{|l|l|c|}
\hline $\begin{array}{l}\text { SUDMINE } \\
\text { (France) }\end{array}$ & $\begin{array}{l}\text { A mining } \\
\text { company } \\
\text { incorporated under } \\
\text { French law, } \\
\text { created in January } \\
\text { 2013. This junior } \\
\text { is not present on } \\
\text { any stock } \\
\text { exchange. }\end{array}$ \\
$\begin{array}{l}\text { Crowdfunding } \\
\text { project. }\end{array}$ & \\
\hline
\end{tabular}

Source: Compiled by authors 